medRxiv preprint doi: https://doi.org/10.1101/2021.08.10.21261843; this version posted August 11, 2021. The copyright holder for this preprint (which was not certified by peer review) is the author/funder, who has granted medRxiv a license to display the preprint in perpetuity.

All rights reserved. No reuse allowed without permission.

\title{
A Comparative Study on the knowledge and attitude of COVID-19 among Urban and Rural populations of Bangladesh
}

Md. Kamal Hossain Ripon, ${ }^{1}$ Noor Muhammad Khan, ${ }^{2}$ A E M Adnan Khan, ${ }^{1}$ Rana Ahmed, ${ }^{1}$ Safia Afrin, ${ }^{1}$ Md. Abu Sayed, ${ }^{1}$ and Md. Mizanur Rahman Moghal,,${ }^{1}$ *

${ }^{1}$ Department of Pharmacy, Mawlana Bhashani Science and Technology University, Tangail1902, Bangladesh

${ }^{2}$ Department of Statistics, Mawlana Bhashani Science and Technology University, Tangail1902, Bangladesh 


\begin{abstract}
Aim: This study is aimed to identify the awareness and behavioral perspective on COVID-19 between urban and rural people of Bangladesh during the period of outbreak.

Methods: A community-based cross-sectional study was conducted in 30 districts of Bangladesh, where 322 participants from urban and 312 from rural area. Participants were selected through convenience sampling.

Results: Rural people are found to be much more inter connected to receive information from neighbor. Regarding the incubation periods and the general symptoms, knowledge differs significantly from urban to rural. Even their precautionary and transmission knowledge is found to associate in most of the cases. During this outbreak, urban people significantly increase their religious habits and also believe that there will some major change of life after outbreak.

Discussion: The study reflected that health education program needed to aware about COVID-19 in both urban and rural in Bangladesh that helps in formulating and executing communication and outbreak management.
\end{abstract}

Key words: COVID-19, outbreak, SARS-CoV-2, awareness, Bangladesh 
medRxiv preprint doi: https://doi.org/10.1101/2021.08.10.21261843; this version posted August 11, 2021. The copyright holder for this preprint (which was not certified by peer review) is the author/funder, who has granted medRxiv a license to display the preprint in perpetuity.

All rights reserved. No reuse allowed without permission.

\section{Introduction}

In 1960, corona virus was first appeared and until 2002, the world considered it as a nonfatal and relatively simple virus. The outbreak of 2002-2003 in China later spread many other countries including United States of America with high mortality rates. After massive fatality, Centers for Disease Control and Prevention and World Health Organization (WHO) declared a state of emergency in 2004 [1-3].An unknown case of pneumonia was reported which clinical symptoms were similar to usual viral pneumonia in Hubei province, China, in December 2019 [4]. The pneumonia was named by the World Health Organization (WHO) and the International Committee on Taxonomy of Viruses as "COVID-19" and 'Severe Acute Respiratory Syndrome Coronavirus2' (SARS-CoV-2) respectively [5]. It is now a pandemic and an international emergency of public health for all over the countries, should step forward to prevent COVID-19 spread called by World Health Organization (WHO) on January $30[6,7]$.

The COVID-19 was confirmed to spread in Bangladesh on March 2020. The first three known cases were reported by the country's Institute of Epidemiology, Disease Control and Research (IEDCR) on 8 March 2020 [8]. Within 4 May, there are a total of 10143 confirmed cases, 182 deaths and Case Fatality Rate (1.79\%) in the country [9].

Bangladesh first imposed nationwide lockdown from March 26 and extended several times for the consequence the Ministry of Public Administration again issued a notification on 4 May, 2020 to extend the general holiday and close all schools, colleges and universities until 14 May, followed by a weekend 15-16 May except all emergency services to resist the spreading of COVID-19 [10].Government of Bangladesh bound to withdraw lockdown due to the economic distress related to suicidal incidences around that time $[11,12]$. 
medRxiv preprint doi: https://doi.org/10.1101/2021.08.10.21261843; this version posted August 11, 2021. The copyright holder for this preprint (which was not certified by peer review) is the author/funder, who has granted medRxiv a license to display the preprint in perpetuity.

All rights reserved. No reuse allowed without permission.

Within the last two weeks of march, 2021, the number of infection and death is tremendously increases and high-risk zone gave a hyper jump from 10 to 38 which is more than half country's 64 districts, according to IEDCR data [13]. From June, 2021, both the number of infection and death dramatically increases and government reimposed a strict lockdown nationwide from July 1-13 and ease the lockdown from July 15-22 for the biggest festival Eid al-Adha and again resume the strict lockdown from July 23 to next two weeks [14-16].

Overall, 1,994,752 infected cases and 19,779 deaths reported in Bangladesh [17] and globally more than 196,002,202 people was infected and 4,193,301 confirm death by COVID 19 on 28th July, 2021 [18].During the period of outbreaks, general people need instant information, a group of population is experience fear, discrimination and stigmatization required special care [19, 20].Furthermore, after the outbreak of severe acute respiratory syndrome (SARS), Middle East respiratory syndrome (MERS), and Ebola, it was recommended that the knowledge and attitudes is connected with the intensity of panic emotion regarding the infectious diseases which make further difficulties to prevent the spread of the diseases [21-26]. While the illness and death are significant, general public or specific communities suffer from fear which make them delay asking help and remain undetected that is very hazardous for controlling transmission during the outbreak of infectious diseases [25]. After the outbreak, the prevalence of post-traumatic stress disorder (PTSD) and major depression of general people increased up to $41 \%$ and $7 \%$ respectively [27].

At this critical situation, it is vital need to understand the public's awareness of COVID-19 in Bangladesh to facilitate the management of outbreak. In this study, we investigate the knowledge and attitude towards COVID-19 of both urban and rural residents of Bangladesh 
medRxiv preprint doi: https://doi.org/10.1101/2021.08.10.21261843; this version posted August 11, 2021. The copyright holder for this preprint (which was not certified by peer review) is the author/funder, who has granted medRxiv a license to display the preprint in perpetuity.

All rights reserved. No reuse allowed without permission.

during this rise period of outbreak to provide the legislators actual field-based data and to support them in the management of this pandemic.

\section{Methods}

To capture the attitude toward COVID-19 among the people of Bangladesh, a community-based cross-sectional study was conducted over a short period (March 2020 to April 2020) during the rise period of outbreak of COVID-19. We have collected the data from 30 convenient districts out of 64 districts. Due to lockdown situation in Bangladesh, it was very hard to collect the data from all the districts. Total 634 participants are encountered in the survey, where we tried to make equal representation of urban and rural people. Respondents were also selected from each district based on their availability to us. In a ward, we have used convenience sampling, a nonprobability sampling technique, in selecting the respondents from the people of Bangladesh. This sampling technique is also known as accidental sampling in many literatures. Convenience sampling involves the sample being drawn from that part of the population that is close to hand. Though it increases the selection bias, it was the only efficient way of collecting data from the people of Bangladesh in lockdown days.

The questionnaire was developed based on the knowledge about COVID-19. We designed the questionnaire into several sections including Transmission, Sign \& Symptoms, Precautions, Treatment, Mental Health, and socio-demographic status of the respondents. Each part is a mirror image of the knowledge about COVID-19 except first and the last part which contains the demographic characteristics and mental health of the participants respectively. In the second section, the questions were designed to reflect the basic knowledge about COVID-19 among rural and urban populations. Knowledge about the transmission is most important part to resist the COVID-19, which was measured through the questions in section three. Similarly, questions 
medRxiv preprint doi: https://doi.org/10.1101/2021.08.10.21261843; this version posted August 11, 2021. The copyright holder for this preprint (which was not certified by peer review) is the author/funder, who has granted medRxiv a license to display the preprint in perpetuity.

All rights reserved. No reuse allowed without permission.

in section four reflect the knowledge regarding sign and symptoms among the mentioned populations. Another most important part in the knowledge of precaution was measured through the questions in the fifth section and a prime factor of contamination rate among them. Questions in the sixth section were designed regarding the treatment option against COVID-19. Finally, our study observed the mental health of the participants during and after the pandemic through the questions of the last section.

One of the uses of the $\chi^{2}$ statistic is in contingency (dependence) testing where $\mathrm{n}$ randomly selected items are classified according to two different criteria, such as when data are classified on the basis of two factors (row factor and column factor), where the row factor has $r$ levels and the column factor has levels. We use chi square test $\left(\chi^{2}\right)$ in our research to test the hypothesis that the two or more factors are independent. $\mathrm{P}$ values of the chi square test are presented in the table.

\section{Results}

Table 1 summarizes the participants according to their demographic characteristics. There is almost equal representation of urban and rural people in our data set, where female participants are found to slightly more convenient than male. We have collected the data from those people who have age 13 or above. Among them, $94 \%$ are found to be educated as they have completed their secondary school certificate. Majority of our respondents are from the middle-class family or higher which ensures that they have the sufficient resources to gather knowledge about COVID-19. Unfortunately, we didn’t find any survivor respondents. 


\begin{tabular}{|c|c|c|c|}
\hline \multicolumn{2}{|c|}{ Demographic Characteristics } & \multirow{2}{*}{$\begin{array}{c}\text { Frequency } \\
322\end{array}$} & \multirow{2}{*}{$\begin{array}{c}\text { Percentage } \\
51\end{array}$} \\
\hline Place of Residence & Urban & & \\
\hline & Rural & 312 & 49 \\
\hline \multirow[t]{2}{*}{ Gender } & Female & 353 & 56 \\
\hline & Male & 281 & 44 \\
\hline \multirow[t]{6}{*}{ Age } & $13-19$ & 165 & 26 \\
\hline & $20-29$ & 189 & 30 \\
\hline & $30-39$ & 88 & 14 \\
\hline & $40-19$ & 92 & 15 \\
\hline & $50-59$ & 66 & 10 \\
\hline & 60 and above & 34 & 5 \\
\hline \multirow[t]{6}{*}{ Education } & $<$ Primary & 40 & 6 \\
\hline & $\mathrm{SSC}$ & 154 & 24 \\
\hline & $\mathrm{HSC}$ & 129 & 20 \\
\hline & Undergraduate & 168 & 26 \\
\hline & Graduate & 102 & 16 \\
\hline & Post Graduate & 41 & 6 \\
\hline
\end{tabular}


Family Status

Participant Group

Division
Lower Class

Middle-Class

Upper Middle-Class

Upper Class

Survivor

Community Member

Health Worker

BARISAL

CHITTAGONG

DHAKA

KHULNA

MYMENSINGH

RAJSHAHI

RANGPUR

SYLHET
107

382

120

25

0

0

629

99

5

1

0

0

25

4

350

55

12

2

106

17

82

13

45

7

14

17

60

19

4

(

9


medRxiv preprint doi: https://doi.org/10.1101/2021.08.10.21261843; this version posted August 11, 2021. The copyright holder for this preprint (which was not certified by peer review) is the author/funder, who has granted medRxiv a license to display the preprint in perpetuity.

All rights reserved. No reuse allowed without permission.

Figure 1 represents the distribution of urban and rural people who have heard about the corona virus, have known about what is corona virus and finally whether they are familiar with the causes of COVID-19 before attending the survey study or not.

Figure 1: Distribution of urban and rural people according their general knowledge about COVID-19.

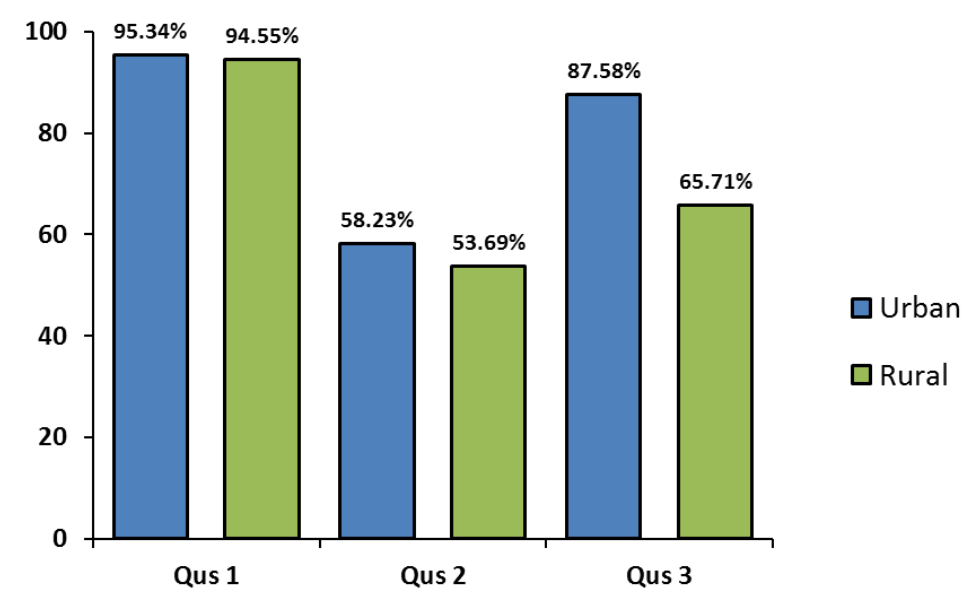

People in urban and rural bear similar general information about COVID-19 on their mind except the cases, where urban people are more knowledgeable about the causes of this novel virus than the rural people.

Figure 2 represents that how the participants from the urban and rural, known about the information of COVID-19. Mass media is key source of knowledge about COVID-19 in both urban and rural area of Bangladesh, where Friends are the secondary source of information there. Compared to urban, people in rural get much information about this virus from their neighbors.

Figure 2: Distribution of knowledge source about COVID-19 in urban and rural. 


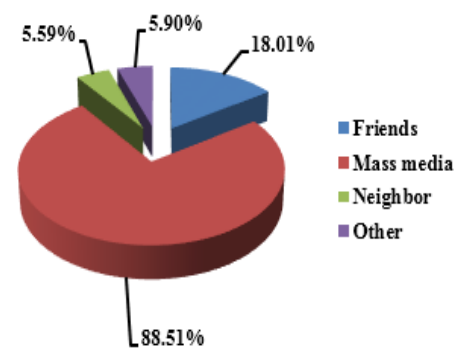

Urban

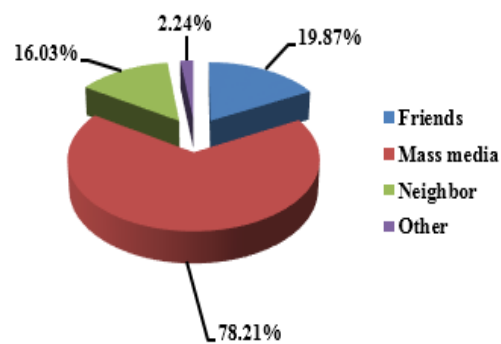

Rural

Table 2 reveals that there no statistically significant difference on general knowledge about COVID-19 between urban and rural people in Bangladesh.

Table 2: Distribution of knowledge level and its source about COVID-19 in urban and rural.

\begin{tabular}{|c|l|c|c|c|}
\hline & & Rural & Urban & p value \\
\hline \multirow{2}{*}{ Knowledge } & Question $1^{1}$ & 94.55 & 95.34 & 0.199 \\
\cline { 2 - 2 } Level & Question $2^{2}$ & 53.69 & 58.23 & \\
\cline { 2 - 2 } & Question $3^{3}$ & 65.71 & 87.58 & \\
\hline \multirow{2}{*}{ Knowledge } & Friends & 19.87 & 18.01 & 0.213 \\
\cline { 2 - 2 } Source & Mass media & 78.21 & 88.51 & \\
\cline { 2 - 2 } & Neighbor & 16.03 & 5.59 & \\
\cline { 2 - 2 } & Other & 2.24 & 5.90 & \\
\hline
\end{tabular}

$\mathrm{P}$ value of chi square test presented in table 2 also shows that source of knowledge of the people in urban area doesn't differ significantly with the source of knowledge of the people in rural area in Bangladesh.

Table 3: Population according to their knowledge on TRANSMISSION

\begin{tabular}{|l|c|c|c|c|c|}
\hline \multirow{2}{*}{ Knowledge of transmission } & \multicolumn{2}{|c|}{ Urban $(\mathrm{n}=322)$} & \multicolumn{2}{|c|}{ Rural $(\mathrm{n}=312)$} & \multirow{2}{*}{ P value } \\
\cline { 2 - 4 } & Number & $\%$ & Number & $\%$ & \\
\hline Spread from person-to-person
\end{tabular}

${ }^{1}$ Heard about corona before attending the survey?

${ }^{2}$ What is the novel corona (COVID-19)?

${ }^{3}$ What are the causes of COVID-19? 


\begin{tabular}{|c|c|c|c|c|c|}
\hline Coughing & 256 & 79.5 & 220 & 70.5 & 0.012 \\
\hline Sneezing & 233 & 72.4 & 205 & 65.7 & 0.084 \\
\hline Direct contact with a sick person & 249 & 77.3 & 193 & 61.9 & 0.000 \\
\hline The surfaces they have recently touched & 177 & 55.0 & 153 & 49.0 & 0.157 \\
\hline Not known & 15 & 4.7 & 5 & 1.6 & 0.048 \\
\hline \multicolumn{6}{|l|}{$\begin{array}{l}\text { Spread through food including } \\
\text { refrigerated or frozen food }\end{array}$} \\
\hline Yes & 82 & 25.5 & 110 & 35.3 & 0.000 \\
\hline No & 132 & 41.0 & 90 & 28.8 & \\
\hline There is no evidence support & 108 & 33.5 & 112 & 35.9 & \\
\hline \multicolumn{6}{|l|}{ Warm weather can stop the outbreak } \\
\hline Yes & 63 & 19.6 & 127 & 40.7 & 0.000 \\
\hline No & 120 & 37.3 & 80 & 25.6 & \\
\hline Yet not confirm & 139 & 43.2 & 105 & 33.7 & \\
\hline \multicolumn{6}{|l|}{$\begin{array}{l}\text { Survive in the surface of the opened } \\
\text { things }\end{array}$} \\
\hline Few hours & 167 & 51.9 & 88 & 28.2 & 0.000 \\
\hline Few days & 75 & 23.3 & 97 & 31.1 & \\
\hline Not known & 80 & 24.8 & 127 & 40.7 & \\
\hline \multicolumn{6}{|l|}{ Transmission from pet or another animal } \\
\hline Agree & 221 & 68.6 & 152 & 48.7 & 0.000 \\
\hline Disagree & 101 & 31.4 & 160 & 51.3 & \\
\hline \multicolumn{6}{|l|}{$\begin{array}{l}\text { Someone spread the virus without being } \\
\text { sick }\end{array}$} \\
\hline Yes & 220 & 68.3 & 122 & 39.1 & 0.000 \\
\hline No & 102 & 31.7 & 190 & 60.9 & \\
\hline
\end{tabular}

Table 3 summarize the participants according to their knowledge on transmission. We have conducted Chi Square test to check the association between the knowledge of urban and rural people in Bangladesh. COVID-19 spreads from person-to-person through several mediums. Knowledge of urban and rural people about these mediums are associated at 5\% level of 
significance except the sneezing and the surface they have recently touched. Their knowledge on food including refrigerated or frozen food, whether COVID-19 spread through food or not, also associated. This result is found to be statistically significant at $1 \%$ level of significance. The opinion of warm weather can stop the outbreak of spreading of this virus is now talk of the town. We have found a significant association between the knowledge of urban and rural people about this opinion. Some people are agreed about the opinion of transmission from pet or another animal, where some others are disagreed. Urban and rural people's knowledge about this transmission is found to be significant. Most of the people in urban area believes that someone can spread the virus without being sick, where most of the rural people bear reverse belief on their mind. This result is also found to be statistically significant at $1 \%$ level of significance.

Table 4: Population according to their knowledge on SIGN \& SYMPTOMS

\begin{tabular}{|c|c|c|c|c|c|}
\hline \multirow{2}{*}{ Knowledge of SIGN \& SYMPTOMS } & \multicolumn{2}{|c|}{ Urban $(n=322)$} & \multicolumn{2}{|c|}{ Rural $(n=312)$} & \multirow{2}{*}{$\mathrm{P}$ value } \\
\hline & Number & $\%$ & Number & $\%$ & \\
\hline \multicolumn{6}{|l|}{ Incubation period of corona virus is - } \\
\hline 1-2 days & 8 & 2.5 & 5 & 1.6 & 0.000 \\
\hline 2-14 days & 293 & 91.0 & 243 & 77.9 & \\
\hline One month & 1 & 0.3 & 4 & 1.3 & \\
\hline Not known & 20 & 6.2 & 60 & 19.2 & \\
\hline \multicolumn{6}{|l|}{ The general symptoms are } \\
\hline Sore throat & 243 & 75.5 & 212 & 67.9 & 0.044 \\
\hline Runny nose & 212 & 65.8 & 170 & 54.5 & 0.004 \\
\hline Nasal congestion & 170 & 52.8 & 117 & 37.5 & 0.000 \\
\hline Shortness of breath & 251 & 78.0 & 175 & 56.1 & 0.000 \\
\hline
\end{tabular}




\begin{tabular}{|c|c|c|c|c|c|}
\hline Difficulty breathing & 252 & 78.3 & 201 & 64.4 & 0.000 \\
\hline Fatigue & 125 & 38.8 & 88 & 28.2 & 0.006 \\
\hline Diarrhea & 107 & 33.2 & 141 & 45.2 & 0.002 \\
\hline \multicolumn{6}{|l|}{ The symptoms are generally looking like pneumonia } \\
\hline Yes & 298 & 92.5 & 280 & 89.7 & 0.269 \\
\hline No & 24 & 7.5 & 32 & 10.3 & \\
\hline \multicolumn{6}{|l|}{ Higher risk for COVID-19 } \\
\hline Children & 35 & 10.9 & 90 & 28.8 & 0.000 \\
\hline Adult & 29 & 9.0 & 40 & 12.8 & 0.157 \\
\hline Older persons & 111 & 34.5 & 108 & 34.6 & 0.990 \\
\hline People aged 65 years and older & 189 & 58.7 & 130 & 41.7 & 0.000 \\
\hline Who have serious underlying medical conditions & 218 & 67.7 & 104 & 33.3 & 0.000 \\
\hline \multicolumn{6}{|l|}{ I have symptoms of COVID-19 } \\
\hline Self-isolate & 301 & 93.5 & 274 & 87.8 & 0.020 \\
\hline Do not visit a hospital, physician's office, & 124 & 38.5 & 98 & 31.4 & 0.073 \\
\hline \multicolumn{6}{|l|}{ lab or healthcare facility without consulting } \\
\hline Mixed with mass people & 3 & 0.9 & 1 & 0.3 & 0.638 \\
\hline
\end{tabular}

Table 4 summarize participants according to their knowledge on sign \& symptoms. We have found significant association between the knowledge of urban and rural people on sign \& symptoms of COVID-19 except few scenarios. The knowledge about the symptoms that they are generally looking like pneumonia insignificantly varies from urban to rural people. We haven't found any significant association between the knowledge of urban and rural people on Adults 
and Older Persons, that they are at higher risk of COVID-19. A small portion of people in both areas, more specifically $0.93 \%$ and $0.32 \%$, believes that they could mixed with mass people even if they are the positive cases of COVID-19.

Table 5: Population according to their knowledge on PRECAUTIONS

\begin{tabular}{|c|c|c|c|c|c|}
\hline \multirow{2}{*}{ Knowledge of PRECAUTIONS } & \multicolumn{2}{|c|}{ Urban $(n=322)$} & \multicolumn{2}{|c|}{ Rural ( $n=312)$} & \multirow{2}{*}{$P$ value } \\
\hline & Number & $\%$ & Number & $\%$ & \\
\hline \multicolumn{6}{|l|}{ You protect yourself and your family- } \\
\hline Stay home & 294 & 91.3 & 270 & 86.5 & 0.073 \\
\hline Avoid social and other outings & 247 & 76.7 & 201 & 64.4 & 0.001 \\
\hline Wash your hands often and well & 243 & 75.5 & 210 & 67.3 & 0.025 \\
\hline $\begin{array}{l}\text { Avoid touching your face, nose, or } \\
\text { mouth with unwashed hands }\end{array}$ & 247 & 76.7 & 207 & 66.3 & 0.000 \\
\hline $\begin{array}{l}\text { Avoid close contact with people } \\
\text { who are sick }\end{array}$ & 241 & 74.8 & 155 & 49.7 & 0.000 \\
\hline \multicolumn{6}{|l|}{ I should wear a medical mask- } \\
\hline If I am sick & 286 & 88.8 & 203 & 65.1 & 0.000 \\
\hline If I am healthy & 80 & 24.8 & 109 & 34.9 & \\
\hline \multicolumn{6}{|l|}{$\begin{array}{l}\text { Clean my hands after coughing } \\
\text { or sneezing- }\end{array}$} \\
\hline $\begin{array}{l}\text { Wash with soap and warm water, } \\
\text { for at least } 20 \text { seconds }\end{array}$ & 303 & 94.1 & 260 & 83.3 & 0.000 \\
\hline $\begin{array}{l}\text { Wash with alcohol-based hand rub } \\
\text { or sanitizer }\end{array}$ & 224 & 69.6 & 167 & 53.5 & 0.000 \\
\hline Clean with tap water is good enough & 16 & 5.0 & 6 & 1.9 & 0.06 \\
\hline \multicolumn{6}{|l|}{$\begin{array}{l}\text { Difference between 'isolation and } \\
\text { quarantine' }\end{array}$} \\
\hline I know & 217 & 67.4 & 189 & 60.6 & 0.088 \\
\hline I don't know & 105 & 32.6 & 123 & 39.4 & \\
\hline \multicolumn{6}{|l|}{$\begin{array}{l}\text { Someone recently returned home } \\
\text { from abroad should }\end{array}$} \\
\hline Visit father-in-law house. & 0 & 0.0 & 0 & 0.0 & \\
\hline Immediately getting married & 0 & 0.0 & 0 & 0.0 & \\
\hline Roaming village or city with & 0 & 0.0 & 0 & 0.0 & \\
\hline
\end{tabular}


girlfriend or wife

Self-isolate for 14 days after the date of return and monitor for symptoms

$\begin{array}{llll}322 & 100.0 \quad 312 & 100.0\end{array}$

Social distancing

Working from home instead of the office

Closing schools and switching

to on-line classes

$\begin{array}{lllll}159 & 49.4 & 110 & 35.3 & 0.000\end{array}$

Postponing large meetings.

$\begin{array}{lllll}174 & 54.0 & 88 & 28.2 & 0.000\end{array}$

6 feet away from other people (COVID-19)

$\begin{array}{lllll}143 & 44.4 & 102 & 32.7 & 0.003\end{array}$

$\begin{array}{lllll}279 & 86.6 & 224 & 71.8 & 0.000\end{array}$

Table 5 summarize the participants according to their knowledge on precautions. The knowledge of urban and rural people on precautions of COVID-19 is found to be significant in most of the cases. Knowledge on the differences between 'isolation and quarantine' are not associated in urban and rural area, where majority of them are known with this. All the people in both areas are agreed that if someone recently returned home from abroad should be self-isolate for 14 days after the date of return and monitor for symptoms.

Table 6: Population according to their knowledge on TREATMENT

\begin{tabular}{|l|c|c|c|c|c|}
\hline \multirow{2}{*}{ Knowledge of TREATMENT } & \multicolumn{2}{l}{ Urban $(\mathrm{n}=322)$} & \multicolumn{2}{c|}{ Rural (n=312) } & \multirow{2}{*}{ P value } \\
\cline { 2 - 5 } & Number & $\%$ & Number & $\%$ & \\
There is any suitable treatment- & 20 & 6.2 & 40 & 12.8 & 0.007 \\
Yes & 302 & 93.8 & 272 & 87.2 & \\
No & & & & & \\
Is there any vaccine for COVID-19? & & & & & \\
Yes & 7 & 2.2 & 12 & 3.8 & 0.316 \\
No & 315 & 97.8 & 300 & 96.2 &
\end{tabular}




\begin{tabular}{|lccccc|} 
Antibiotics has no role in Corona virus & & & & & \\
TRUE & 242 & 75.2 & 254 & 81.4 & 0.070 \\
FALSE & 80 & 24.8 & 58 & 18.6 & \\
& & & & & \\
Patients are much more vulnerable- & & & & & \\
Hypertension & 166 & 51.6 & 105 & 33.7 & 0.000 \\
Asthma and COPD & 265 & 82.3 & 230 & 73.7 & 0.012 \\
Psychiatric patients & 101 & 31.4 & 51 & 16.3 & 0.000 \\
Diabetes patients & 202 & 62.7 & 180 & 57.7 & 0.224 \\
Cardiac patient & 192 & 59.6 & 140 & 44.9 & 0.000 \\
Kidney failure & 164 & 50.9 & 92 & 29.5 & 0.000 \\
Other & 77 & 23.9 & 51 & 16.3 & 0.023 \\
\hline
\end{tabular}

Table 6 summarize the participants according to their knowledge on treatment. A large portion of the people in both areas know that there is no suitable treatment or vaccine or anti-biotic for COVID-19. Their knowledge on suitable treatment is significantly associated, where knowledge on vaccine and anti-biotic aren't. Patients of several diseases are much more vulnerable from this virus. Knowledge about hypertension, asthma and COPD, psychiatric, cardiac, kidney failure, and other patients except diabetic patients are significantly associated in both areas.

Table 7: Population according to effect on MENTAL HEALTH

\begin{tabular}{|l|c|c|c|c|c|}
\hline \multirow{2}{*}{\multicolumn{1}{|c|}{ Effects on MENTAL HEALTH }} & \multicolumn{2}{|c|}{ Urban (n=322) } & \multicolumn{2}{c|}{ Rural (n=312) } & \multirow{2}{*}{ P value } \\
\cline { 2 - 5 } & Number & $\%$ & Number & $\%$ & \\
\hline I am likely to get Coronavirus & & & & & \\
Strongly disagree & 117 & 36.3 & 106 & 34.0 & 0.003 \\
\hline
\end{tabular}




\begin{tabular}{|c|c|c|c|c|c|}
\hline Disagree & 119 & 37.0 & 78 & 25.0 & \\
\hline Agree & 71 & 22.0 & 116 & 37.2 & \\
\hline Strongly agree & 15 & 4.7 & 12 & 3.8 & \\
\hline \multicolumn{6}{|c|}{ Worried about getting the Coronavirus } \\
\hline Strongly disagree & 29 & 9.0 & 21 & 6.7 & 0.010 \\
\hline Disagree & 43 & 13.4 & 33 & 10.6 & \\
\hline Agree & 160 & 49.7 & 131 & 42.0 & \\
\hline Strongly agree & 90 & 28.0 & 127 & 40.7 & \\
\hline \multicolumn{6}{|c|}{ Belief regarding the infected people- } \\
\hline Will die & 32 & 9.9 & 29 & 9.3 & 0.333 \\
\hline No comments & 162 & 50.3 & 176 & 56.4 & \\
\hline Will recover & 128 & 39.8 & 107 & 34.3 & \\
\hline \multicolumn{6}{|c|}{ Religious habits change during outbreak } \\
\hline Increased & 203 & 63.0 & 146 & 46.8 & 0.000 \\
\hline No change & 88 & 27.3 & 131 & 42.0 & \\
\hline Decreased & 31 & 9.6 & 35 & 11.2 & \\
\hline \multicolumn{6}{|c|}{ Life will be changed in a major way } \\
\hline \multicolumn{6}{|l|}{ after outbreak } \\
\hline Agree & 285 & 88.5 & 259 & 83.0 & 0.062 \\
\hline Disagree & 37 & 11.5 & 53 & 17.0 & \\
\hline
\end{tabular}


Everyone should follow the government

instructions

Strongly disagree

2

0.6

20

6.4

0.000

Disagree

3

0.9

6

1.9

Agree

42

13.0

66

21.2

Strongly agree

275

85.4

220

70.5

Feeling Comfort going to outside of home

Yes

20

6.2

42

13.5

0.003

No

302

93.8

270

86.5

Table 7 summarize the participants according to effect on mental health. All the questions in this section are Likert questions except the last one. We have conducted the Cochran-Armitage test to check the association. This association test can be performed on a contingency table with one ordered nominal variable and one non-ordered nominal variable. The effect of COVID-19 on the mental health of urban and rural people in Bangladesh is found to be significantly associated from many dimensions.

\section{Discussion}

Our study shows that urban people are more knowledgeable than rural people regarding causes of COVID-19. This is because, the people in urban and rural area in Bangladesh doesn't have the similar access to gather knowledge on various issues. Though mass media is the largest source of knowing about COVID-19 here, rural people are mostly dependent on the broadcast media and their neighbors. However, urban people are found to be more aware about this virus than the 
medRxiv preprint doi: https://doi.org/10.1101/2021.08.10.21261843; this version posted August 11, 2021. The copyright holder for this preprint (which was not certified by peer review) is the author/funder, who has granted medRxiv a license to display the preprint in perpetuity.

All rights reserved. No reuse allowed without permission.

rural one. They are mostly dependent on internet, especially social sites, scientific journals, broadcast media etc. These areas are the sources of knowledge about COVID-19 to them. Urban and rural residents of the China, where the first COVID-19 patient was reported, have the moderate level of COVID-19 knowledge and they show a positive attitude toward the disease [30].The urban respondents of Pakistan, a nearby country of Bangladesh, had higher knowledge about COVID-19 disease as compared to rural respondents. Their hygienic behavior was better than rural respondents [31]. However, our data also represents that rural people significantly carry lack of knowledge about transmission as well as precautions. On the other hand, both urban and rural people know that there is no treatment of this disease but rural people are not taking much precautions, our thinking this may be due to the lack knowledge and awareness. Choi and Kim also described in their studies infection-control knowledge directly related with attitudes and practice [21].Ajzen and Fishbein revealed a significant correlation among knowledge, attitudes and practice [28]. Other studies also support this finding where they mentioned lack of awareness in Anhui province of China [29]. Impact of this pandemic on the global health and mental health is reported in recent studies [28]. Our study also shows that both urban and rural people are worried about getting the corona virus and believe that after outbreak life will be changed in a major way. Some researchers tried to identify the root cause of panic in the community, where they reported that the Muslim communities in the rural area facing the COVID-19 Pandemic attempts to find refuge from the plague and hope for survival [32]. However urban people significantly increased their religious habit during this outbreak.

So far, we know, previously population-based studies regarding COVID-19 either field based or online based were conducted in the city area only. In our country, internet is not easily accessible, especially in rural area. Moreover, the people in the rural area are not habituated 
medRxiv preprint doi: https://doi.org/10.1101/2021.08.10.21261843; this version posted August 11, 2021. The copyright holder for this preprint (which was not certified by peer review) is the author/funder, who has granted medRxiv a license to display the preprint in perpetuity.

All rights reserved. No reuse allowed without permission.

regarding this on-line survey. Face to face survey is highly recommended here to find out the exact scenario.

In contrast we conducted our study in both urban and rural areas following heath guidelines strictly and also covered a good number of participants in both areas. On the other hand, the limitation of our study, we can't include survivor in this study because survivor wasn't available at that time. Our recommendation to conduct similar studies in different developing countries in the world for more evidence for the management of pandemic because rural people is less advanced in different perspectives than urban people.

COVID-19 is now a pandemic and the situation are like time bomb as no medical treatment is too much effective and no proper vaccine yet discovered. Bangladesh become a highest worse condition regarding this infectious disease in the world due to overpopulated and lack of awareness. In this circumstance only people's awareness in Bangladesh can help to protect us. This cross-sectional study was carried out to identify the awareness and behavioral perspective on COVID-19 between urban and rural people. Awareness regarding COVID-19 was unsatisfactory in rural residents as compared to urban. Based on the results of our study, we can conclude that improvement of COVID-19 knowledge, attitudes and promotion of awareness among residents by effective health education programs is needed especial care needed in rural areas. Our belief this survey will provide valuable information to the legislators regarding the perceptions of urban and rural population for the management of pandemic.

\section{References:}

1. Centers for Disease Control and Prevention (CDC). Update: Outbreak of severe acute 
respiratory syndrome -Worldwide, 2003. Morb Mortal Wkly Rep. 2003;52(12):241-248. doi:10.1001/jama.289.16.2059

2. WHO | Update 31 - Coronavirus never before seen in humans is the cause of SARS. https://www.who.int/csr/sars/archive/2003_04_16/en/. Accessed May 12, 2020.

3. Al-Osail AM, Al-Wazzah MJ. The history and epidemiology of Middle East respiratory syndrome corona virus. Multidiscip Respir Med. 2017;12(1):1-6.

4. Huang C, Wang Y, Li X, et al. Clinical features of patients infected with 2019 novel coronavirus in Wuhan, China. Lancet. 2020;395(10223):497-506.

5. Liu Y, Gayle AA, Wilder-Smith A, Rocklöv J. The reproductive number of COVID-19 is higher compared to SARS coronavirus. J Travel Med. 2020;27(2):1-6.

6. Liang K. Mathematical model of infection kinetics and its analysis for COVID-19, SARS and MERS. Infect Genet Evol. 2020;82(March):104306.

7. Zhong BL, Luo W, Li HM, et al. Knowledge, attitudes, and practices towards COVID-19 among Chinese residents during the rapid rise period of the COVID-19 outbreak: a quick online cross-sectional survey. Int J Biol Sci. 2020;16(10):1745-1752.

8. http://www.iedcr.gov.bd. msev`weÁwß. Bangladesh Covid-19 Updat Inst Epidemiol Dis Control Res.:23-25.

9. COVID-19. H who. int/bangladesh/emergencies/coronavirus-diseas.-(covid-19)update/coronavirus-disease-(covid-2019)-bangladesh-situation-reports (2020).

10. COVID-19: Bangladesh to extend lockdown until May 16. https://www.aa.com.tr/en/asia-pacific/covid-19-bangladesh-to-extend-lockdown-untilmay-16/1826659. Accessed May 12, 2020.

11. Bhuiyan, A. I., Sakib, N., Pakpour, A. H., Griffiths, M. D., \& Mamun, M. A. (2020). 
medRxiv preprint doi: https://doi.org/10.1101/2021.08.10.21261843; this version posted August 11, 2021. The copyright holder for this preprint (which was not certified by peer review) is the author/funder, who has granted medRxiv a license to display the preprint in perpetuity.

All rights reserved. No reuse allowed without permission.

COVID-19-related suicides in Bangladesh due to lockdown and economic factors: case study evidence from media reports. International Journal of Mental Health and Addiction, $1-6$.

12. Mamun, M. A., \& Griffiths, M. D. (2020). First COVID-19 suicide case in Bangladesh due to fear of COVID-19 and xenophobia: Possible suicide prevention strategies. Asian journal of psychiatry, 51, 102073.

13. Molla, M. A.-M. (2021, April 7). Half the country at high risk. The Daily Star. https://www.thedailystar.net/frontpage/news/half-the-country-high-risk-2073313.

14. COVID-19. (n.d.). http://dashboard.dghs.gov.bd/webportal/pages/covid19.php.

15. Report, S. D. (2021, July 12). Govt to EASE 'strict lockdown' from July 15 to 22. The Daily Star. https://www.thedailystar.net/news/bangladesh/governance/news/govt-easestrict-lockdown-july-15-22-2128321.

16. Bangladesh resumes strict LOCKDOWN after Eid holidays. Anadolu Ajans1. (n.d.). https://www.aa.com.tr/en/asia-pacific/bangladesh-resumes-strict-lockdown-after-eidholidays/2311955.

17. Administrator. (n.d.). COVID-19 daily press release. https://old.iedcr.gov.bd/website/index.php/component/content/article/11-others/227pressrelease.

18. Coronavirus cases: Worldometer. (n.d.). https://www.worldometers.info/coronavirus/.

19. Craddock S, Markel H. Quarantine! East European Jewish Immigrants and the New York City Epidemics of 1892. J Am Hist. 2001;88(3):1100.

20. McClain CJ. In search of equality: the Chinese struggle against discrimination in nineteenth-century America. Berkeley (CA): University of California Press; 1994. 
medRxiv preprint doi: https://doi.org/10.1101/2021.08.10.21261843; this version posted August 11, 2021. The copyright holder for this preprint (which was not certified by peer review) is the author/funder, who has granted medRxiv a license to display the preprint in perpetuity.

All rights reserved. No reuse allowed without permission.

21. Choi JS, Kim KM (2018) Infection-control knowledge, attitude, practice, and risk perception of occupational exposure to Zika virus among nursing students in Korea: a cross-sectional survey. J Infect Public Health 11:840-844.

22. Madhav N, Oppenheim B, Gallivan M et al (2017) Pandemics: risks, impacts, and mitigation, chap 17. In: Jamison DT, Gelband H, Horton S et al (eds) Disease control priorities: improving health and reducing poverty, 3rd edn. The International Bank for Recon.

23. Almutairi KM, Al Helih EM, Moussa M et al (2015) Awareness, attitudes, and practices related to coronavirus pandemic among public in Saudi Arabia. Family Community Health 38:332-340.

24. Yap J, Lee VJ, Yau TY et al (2010) Knowledge, attitudes and practices towards pandemic influenza among cases, close contacts, and healthcare workers in tropical Singapore: a crosssectional survey. BMC Public Health 10:442.

25. Person B, Sy F, Holton K, Govert B, Liang A, Sars N. 03-0750. 2004;10(2).

26. Tao N. An analysis on reasons of SARS-induced psychological panic among students. Journal of Anhui Institute of Education. 2003; 21: 78-9.

27. Torales J, O’Higgins M, Castaldelli-Maia JM, Ventriglio A. The outbreak of COVID-19 coronavirus and its impact on global mental health. Int J Soc Psychiatry. 2020:3-6.

28. Ajzen I, Fishbein M (2005) The influence of attitudes on behavior. In: Albarraci'n D, Johnson BT, Zanna MP (eds) The handbook of attitudes. Lawrence Erlbaum Associates, Mahwah, pp 173-221.

29. Chen Y, Jin Y, Zhu L et al. (2020) The network investigation on knowledge, attitude and practice about Novel coronavirus pneumonia of the residents in Anhui Province 
medRxiv preprint doi: https://doi.org/10.1101/2021.08.10.21261843; this version posted August 11, 2021. The copyright holder for this preprint (which was not certified by peer review) is the author/funder, who has granted medRxiv a license to display the preprint in perpetuity.

All rights reserved. No reuse allowed without permission.

Zhonghua yu fang yi xue za zhi, Chinese journal of preventive medicine, 54:E004.

30. Yue, S., Zhang, J., Cao, M., \& Chen, B. (2021). Knowledge, Attitudes and Practices of COVID-19 Among Urban and Rural Residents in China: A Cross-sectional Study. Journal of community health, 46(2), 286-291. https://doi.org/10.1007/s10900-020$\underline{00877-\mathrm{X}}$

31. Haq, S. ul, Shahbaz, P., \& Boz, I. (2020). Knowledge, behavior and precautionary measures related to COVID-19 pandemic among the general public of Punjab province, Pakistan. The Journal of Infection in Developing Countries, 14(08), 823-835. https://doi.org/10.3855/jidc. 12851

32. Wibisono, Muhammad Y., Truna, Dody S., \& Rahman, Mohammad T.. (2021). Turning religion from cause to reducer of panic during the COVID-19 pandemic. HTS Theological Studies, 77(4), 1-8. https://dx.doi.org/10.4102/hts.v77i4.6366

Acknowledgements: There was no financial and material support in this study.

\section{Compliance with ethical standards}

Conflict of interest: The authors declare that they do not have any conflictof interest.

Ethical approval: The study was approved by the research ethics committeeof the Department of Pharmacy, Mawlana Bhashani Science and Technology University. 